\title{
Attitude Of Head Teachers Towards The Instructional Supervision Of Beginning Senior High School Economics Teachers
}

\author{
Dacoster Kwaku Boakye *, Francis Arthur ${ }^{* * *}$ \\ * Department of Business and Social Sciences Education, Faculty of Humanities and Social Sciences Education, University of Cape Coast, Cape \\ Coast, Ghana \\ ** Department of Business and Social Sciences Education, Faculty of Humanities and Social Sciences Education, University of Cape Coast, Cape \\ Coast, Ghana
}

DOI: 10.29322/IJSRP.12.01.2022.p12119

http://dx.doi.org/10.29322/IJSRP.12.01.2022.p12119

\begin{abstract}
The attitude of head teachers towards instructional supervision has a greater impact on the professional development of Senior High School Beginning Economics teachers' professional development. This study examined the attitude of Head teachers towards the instructional supervision of beginning Senior High School Economics teachers in the Kumasi Metropolis. The study was a quantitative research which adopted the descriptive cross-sectional survey design. In all, 98 Head teachers were selected for the study. Data were collected through a 5-point Likert scale questionnaire from strongly agree to strongly disagree. The descriptive statistics which comprise mean and standard deviation were used to analyse the data that was obtained. The study found out that Head teachers attach a great level of importance to beginning Economics teachers' instructional supervision. Again, it was found out that Head teachers encounter the fundamental challenges of the instructional supervision process. Lastly, it was found out that there is a statistically significant difference between the level of importance private and public Head teachers attach to Beginning SHS Economics teachers' instructional supervision. It was recommended that the Ghana Education Service must set up an independent body to monitor the supervisory activities of Public Senior High School Heads.
\end{abstract}

Index Terms- Attitude, Economics, Instructional supervision, Professional development

\section{INTRODUCTION}

$\mathrm{O}$ ver a long period, instructional supervision had been based on hierarchical principles. The role of the teacher was to impart basic truths to students, whereas the role of the supervisor was to serve as the "inspector" to ensure the curriculum had been followed and essential skills had been learned (Ebmeier \& Nicklaus, 2009). As this orientation towards teacher instructional supervision became more common, many teachers were afraid to ask supervisors for help or to seek collegial assistance for fear that doing so would expose weaknesses in their teaching, which could be reflected later in low evaluations and possible punitive actions. As Ebmeier and Nicklaus noted, instructional supervision as an evaluation tool reduced the possibility of nurturing collegiality, collaboration, and reflective practice. As results of the effect that the inspection was having on teachers however, researchers saw the need to utilize the term supervision instead of inspection.

Redefinition of instructional supervision, according to Sergiovanni and Starratt (2008) includes the disconnection of instructional supervision from hierarchical roles and is viewed as a more democratic and professional process, involving multiple skills that are equally available to teachers and supervisors. This new instructional supervision embraces different configurations of teachers as colleagues working together to increase the understanding of their practice. It establishes a new connection with developmental roles. “... Staff development and instructional supervision are now joined in such a way that they are often indistinguishable".

One of the most critical Challenges facing the teaching profession is how to improve the development of beginning teachers. Beginning teachers find their first few years of teaching a trying and often defeating experience (Glatthorn, 2010). Entrance into the teaching profession is marked by an initial period of challenges and opportunities. Teachers begin their careers facing the most difficult assignments (Huling-Austin, 2000) with a lack of time for planning, instructional supervision, and interaction with colleagues (Odell \& Ferraro, 2002). Educational leaders in schools must "support successful teacher induction in the ways they respond to these beginning teachers' needs" (Reiman \& Thies-Sprinthall, 1998, p. 13).

As Robinson (2008) pointed out, to be successful, beginning teachers must meet their challenges with perseverance, hard work, and quality assistance from experienced teachers and administrators who are willing to provide and recognize extensive support for beginning teachers during the first year or two of their teaching careers. Effective instructional supervision and coaching programmes at the induction level by Head teachers have been found to ameliorate beginning teachers concerns, and to increase beginning teacher focus on instruction (Huling-Austin, 2000).

The Challenges experienced by beginning teachers should not lead supervisors to conclude that all induction programmes should focus solely on survival issues (Glatthorn, 2010). Professional development, as a desired outcome of instructional supervision, must be a key issue in induction, given that beginning 
teachers are future educational leaders (Reiman \& ThiesSprinthall, 2008).

\section{StATEMENT OF THE PROBlem}

Instructional supervision is a very important aspect of Head teacher's role in a school. For any system to function effectively and achieve its objective, keen instructional supervision is a vital role in success (Chen, 2013). It has become very difficult for beginning Economics teachers to develop themselves professionally (Dwamena 2013). One main reason is attributed to the elapses in the attitude of supervisors in carrying out their supervisory role. According to Badu and Antwi (2012), Head teachers in the Kumasi metropolis are performing their supervisory role yet beginning SHS economics teachers who are posted over the years are not satisfied with the kind of supervision they have been receiving. Also according to Badu's findings ten beginning SHS Economics teachers are posted into the metropolis every year and that necessitate for a critical look into then issue at hand. To get a better understanding of the issues dealt with in this study, it is essential to provide the context for Kumasi Metropolis in the Ashanti region of Ghana regarding instructional supervision and professional development.

In Nigeria, Abiola (2011) revealed that beginning teachers are passionate and ready to develop themselves professionally. Abiola's study further brought to light that the professional development of these teachers can be achieved through effective instructional supervision. In Abiola's research, it was also revealed that Head teachers are the principal agents responsible for the instructional supervision of teachers.

Also, Badu and Antwi (2012) in examining the professional development of beginning Economics teachers in Senior High Schools in the Ashanti Region of Ghana, identified that most of these teachers are not able to develop themselves professionally through the instructional supervision that they receive from their supervisors. Dwamena (2013) study also revealed that there are differences in the approaches that public and private Head teachers use in the instructional supervision of beginning High School Economics.

Badu and Antwi (2012), studies further revealed that beginning SHS Economics teachers' professional development is not directly affected by the instructional supervision that is conducted by their supervisors in the Metropolis. This in a way has created a difference between instructional supervision and professional development of beginning teachers (Hallman, 2012). Again, Ansong (2013) postulated that beginning Economics teachers in the Kumasi Metropolis lag in terms of their professional development as compared to their older counterparts. According to Amoateng (2015), however, it appears Head teachers in the Kumasi Metropolis do not treat older and beginning teachers equally when it comes to instructional supervision, therefore this seeming difference in the attitudes of Head teachers towards instructional supervision could be a leading factor.

In the Ghanaian context, most of the studies (Badu \& Antwi, 2012; Asamoah; 2013; Saahene, 2014; Danso, 2017) conducted on instructional supervision focused on instructional supervision in general and other subject discipline. It appears little work has been done in Ghana to find out the attitude of Head teachers towards the instructional supervision of beginning Economics teachers.
Also the studies of Dwamena (2013) and Amoateng (2015) cite excerpts of differences between instructional supervision and professional development of beginning teachers. It therefore suggests that the attitude or how the Head teachers view instructional supervision is at play in beginning High School Economics teachers' professional development in schools. This current study, therefore, sought to examine the issues in the attitude of Head teachers towards instructional supervision that shape the professional development of beginning Economics teachers in the Kumasi Metropolis.

\section{Purpose of the Study}

The study sought to examine the attitude of Head teachers' towards the instructional supervision of beginning Senior High School Economics teachers' in selected Senior High Schools in the Kumasi Metropolis. Specifically, the study was intended to;

1. examine the level of importance that Head teachers attach to the instructional supervision of beginning SHS Economics teachers.

2. identify the challenges that Head teachers encounter in supervising Beginning SHS Economics teachers.

3. assess the approach Head teachers use in supervising Beginning SHS Economics teachers.

4. examine the role Head teachers play in supervising Beginning SHS Economics teachers.

\section{Research Hypotheses}

The study tested these hypotheses:

1. $\mathrm{H}_{0:}$ There is no statistically significant difference between the level of importance male and female school Heads attach to Beginning SHS Economics teachers' instructional supervision.

2. $\mathrm{H}_{0 \text { : }}$ There is no statistically significant difference between the level of importance public and private school Heads attach to Beginning SHS Economics teachers' instructional supervision.

\section{RESEARCH METHODS}

\section{Research Design, Population, Instrument}

The choice of this method was informed by the opinion of Creswell (2014) that cross-sectional survey design provides a quantitative or numeric description of trends, attitudes, or opinions of a population by studying a sample of that population.

\section{Population}

The population for this study comprised all Head and assistants Head teachers in the public and private Senior High Schools in the Kumasi Metropolis. In all, there are 67 Senior High Schools in the Kumasi Metropolis (GES, 2019) of which 26 are public schools while the remaining 41 are private schools. The total number of Head and Assistant teachers in the Metropolis is 134, with the public school Head teachers numbering 52 and private Head teachers 82 . In all, a total of 134 participants formed the target population for the study.

\section{Sample and Sampling Procedures}

The multi-stage sampling technique was used in selecting the sample size. The sampling was conducted at two levels. 
Firstly, the stratified sampling technique was used to place the Senior High Schools in the Kumasi Metropolis into two strata: Public and Private SHS's. The stratification variables that was used is the school type within the Metropolis. Secondly, the purposive sampling technique was used in selecting 49 (20 public and 29 private) Senior High Schools selected from the sixty-seven (67) Senior High Schools in the Metropolis to constitute the sample. A list of the schools in the Metropolis was collected from the Kumasi Metropolitan Education Office. These 49 schools were purposively selected because these schools were having beginning Economics teachers.

The researcher then employed the census method to select all the 98 Head teachers from the forty-nine schools. This technique was used due to the small number of Head teachers in each school so, there was no need to sample. The census method was employed because large sample gives better judgment over smaller ones provided such large samples are available and accessible (Gall, Gall \& Borg, 2007). The technique helped the researcher to involve every Head teacher in all the forty-nine schools.

\section{Data Collection Instrument}

The questionnaire was the main instrument used to elicit responses from the Head teachers who participated in the study. In other words, the attitude survey questionnaire developed by Sergiovanni and Starratt (2007) was adapted as the instrument for data collection. The questionnaire was used for the study because it is appropriate for survey work and also affords the respondents adequate time to give well thought out answers (Kothari, 2004).

\section{Data Collection Procedures}

Before administering the instrument, the researcher visited the schools and a letter of introduction from the Head of Department, Department of Business and Social Sciences Education (DOBSSE), of the University of Cape Coast was given to the heads of these schools who were also part of the respondents. The questionnaire was administered two research assistants. It is ethical in research to assure respondents of their confidentiality and anonymity; hence the questionnaire was accompanied with a cover letter to this effect and to crave their maximum co-operation.

\section{Techniques of Data Analysis}

In addressing the research questions, descriptive statistics including means and standard deviations were computed and inferential statistics such as independent sample T-test was computed.

\section{Presentation of Results}

Research Question One: What Level of Importance Do Head Teachers Attach to the Instructional supervision of Beginning SHS Economics Teachers?

\section{Table 1: The Level of Importance Head Teachers Attach to the Instructional Supervision of Beginning SHS Economics} Teachers

\begin{tabular}{lcc}
\hline Statement & Mean & SD \\
\hline I supervise my supervisees regularly & 1.65 & .64 \\
I supervise my teachers on time & 1.56 & .54 \\
I am concerned with my total development and ways to help my supervisees improve in their & 1.48 & .65 \\
teaching & 1.95 & .94
\end{tabular}

I ascertain the strengths and limitations of the schools and set suitable targets for the progress 1.98 of the educational institutions.

I share inform the management, parents about the Challenges of the school and seek their $\quad \begin{array}{lll}1.51 & .72\end{array}$ help in solving them out

I promote the professional growth of all school personnel especially that of the teachers by organizing various need-based in-service programmes of varied types such as workshops, seminars, etc.

I identify the factors responsible for promoting or hindering the progress of the schools an thereby taking steps to explore or to control them. 
greater level of importance is attached to the instructional supervision of Beginning SHS Economics teachers' instructional supervision. The average standard deviation score (SD) of .76 also suggests that the responses of the respondents were uniform.

The highest mean value recorded was $(\mathrm{M}=1.98, \mathrm{SD}=0.87)$, which is the statement that school Heads can ascertain the strengths and limitations of the schools and set suitable targets for the progress of their educational institutions. In furtherance with the frequency of instructional supervision, the majority $(\mathrm{M}=1.65$, $\mathrm{SD}=.64$ ) of Head teachers affirmed that they can supervise their teachers regularly. In telling details of their time consciousness, Head teachers agreed $(\mathrm{M}=1.56, \mathrm{SD}=.54)$ that they supervise their teachers on time.
As clearly shown in Table 8 , the lowest mean value recorded was $(\mathrm{M}=1.48, \mathrm{SD}=.65)$, and it is with the statement that Head teachers are concerned with the total development and ways to help beginning teachers improve upon their teaching. This implies that a majority of the respondents agreed that they educate beginning Economics teachers on the appropriate teaching methods that enables them to enhance their teaching.

Research Question Two: What Challenges Do Head Teachers Encounter in Supervising Beginning SHS Economics Teachers?

Table 1: Challenges Head Teachers Encounter in Supervising Beginning SHS Economics Teachers

\begin{tabular}{lll}
\hline Statement & Mean & SD \\
\hline I am not clear about the boundaries of instructional supervision & 1.92 & .68 \\
The distribution of tasks between these levels is seldom clear & 2.23 & .85 \\
Financial constraints make it difficult to implement instructional supervision tasks & 2.34 & 1.14 \\
and acquire support services. & 2.65 & 1.30 \\
Lack of means of transport makes impeaches my instructional supervision duties & 2.37 & 1.25 \\
& 3.48 & 1.23 \\
Overload of tasks makes my instructional supervision stressful. & 3.31 \\
Supervisees are disrespectful and do not implement suggestions offered to them. & 1.14 \\
Indiscipline on the part of supervisees makes my task difficult. & 2.61 \\
\hline Average Mean/Average Standard Deviation & 1.08 \\
\hline
\end{tabular}

Source: Field survey, 2020

Table 9 shows results on the challenges Head teachers encounter in supervising Beginning SHS Economics teachers. From Table 9, the overall average mean of 2.61 compared to the cut-off point of 3 mean scores for an agreement to the statement, indicates that Head teachers are primarily faced with the basic challenges of instructional supervision. The average standard deviation score $(\mathrm{SD}=1.11$ ) also suggests that Head teachers' responses to the items on this particular subscale were heterogeneous.

The respondents disagreed that, "supervisees are disrespectful and do not implement suggestions offered to them" and this recorded the highest mean value $(\mathrm{M}=3.48, \mathrm{SD}=1.23)$. However, from Table 9, the lowest mean value recorded was (M $=1.92, \mathrm{SD}=0.68)$ and is about the statement that "I am not clear about the boundaries of instructional supervision". This implies that there is some level of overlap of responsibility among the various supervisors responsible for instructional supervision.

Research Hypothesis 1: There is no Statistically Significant Difference between the Level of Importance Male and Female School Heads Attach to the Instructional Supervision of Beginning Economics Teachers.

This hypothesis was meant to find out whether there was any statistically significant difference between the level of importance male and female school heads attach to the instructional supervision of beginning Economics teachers. The independent variable was gender made up of male and female school Heads and the dependent variable was the mean level of importance attached to instructional supervision. To address the research hypothesis, the data that was obtained was analysed using the independent sample t-test at a significance level of 0.05 . Table 12 presents the results on the differences between the male and female school heads level of importance towards instructional supervision.

Table 2: Differences Between Male and Female school Heads Level of Importance Attach to the Instructional Supervision of Beginning SHS Economics Teachers

\begin{tabular}{llllll}
\hline Gender & $\mathrm{M}$ & $\mathrm{SD}$ & $\mathrm{t}$ & $\mathrm{df}$ & $\rho$ \\
\hline Male & 2.20 & .54 & -.163 & .384 & .871 \\
Female & 2.21 & .61 & & & \\
\hline *Significance level & 05 & & & &
\end{tabular}

*Significance level .05

From Table 12, the results show that there is no statistically significant difference between the level of importance the male school heads attach to instructional supervision $(\mathrm{M}=2.20, \mathrm{SD}=$ $.54)$ and the female school Heads $(\mathrm{M}=2.21, \mathrm{SD}=.61) ; t(384)=$ $-.163, p>.05$, (two-tailed). This means that there were no differences in the mean value of the male school Heads (2.20) and the female school Heads (2.21). It can, therefore, be concluded that 
both genders attach the same level of importance to instructional supervision.

Research Hypothesis 2: There is no Statistically Significant Difference between the Level of Importance Public and Private School Heads Attach to the Instructional Supervision of Beginning Economics Teachers.

Research hypothesis two was meant to determine whether there is any statistically significant difference between the level of importance public and private Head teachers attach to the instructional supervision of Beginning SHS Economics teachers. The public and private SHS Head teachers were the independent variables and the average mean of the level of importance Head teachers attach to the instructional supervision of Beginning SHS Economics teachers was the dependent variable. To address the research hypothesis, the data obtained were analysed using the independent sample t-test at a significance level of 0.05 . Table 13 presents a summary of the results in terms of the hypothesis that, there is no statistically significant difference in the level of importance attached to instructional supervision between private and public SHS Head teachers.

Table 3: Differences Between Public and Private school Heads Level of Importance Attach to the Instructional Supervision of Beginning SHS Economics Teachers

\begin{tabular}{llllll}
\hline $\begin{array}{l}\text { School } \\
\text { Proprietorship }\end{array}$ & $\mathrm{M}$ & $\mathrm{SD}$ & $\mathrm{t}$ & $\mathrm{df}$ & $\rho$ \\
\hline Private & 2.21 & .39 & -2.389 & 97 & .020 \\
Public & 1.94 & .22 & & & \\
\hline
\end{tabular}

*Significance level .05

Source: Field survey, 2020.

From Table 13, it can be observed that there is a difference in terms of the mean values for the private and public Head teachers with the mean of the private Head teachers exceeding that of the public Head teachers by 0.27 . However, to test whether the difference in the mean values was statistically significant, an independent t-test was used. First, the Levene's test for equality of variances indicated that the variances for the two groups were equal $(\mathrm{F}=5.495, .020<.05)$, and therefore a test for equal variances was used. The mean value of public Head teachers' level of importance $(\mathrm{M}=1.94, \mathrm{SD}=.22)$ is significantly lower $(\mathrm{t}=$ $2.389, \mathrm{df}=97, .020<.05)$ than that of the private school's Head teachers $(\mathrm{M}=2.21, \mathrm{SD}=.39)$. This suggests that public and private school head teachers attach a different level of importance to the instructional supervision of Beginning Economics teachers.

\section{Discussion OF RESUlts}

The first research question sought to find out the level of importance Head teachers attach to the instructional supervision of Beginning SHS Economics teachers. The results from the study indicated that the majority of the head teachers attach importance to the instructional supervision of Beginning SHS Economics teachers. This finding supports the assertion of Omane (2015) that school heads attach a greater level of importance when it comes to the instructional supervision of beginning teachers. This finding further validates the views of several researchers (Keeler \& Steinhorst, 1995; Onwuegbuzie \& DaRose-Voseles, 2001; Dale, Nasir \& Sullivan, 2005). The finding also lends credence to the opinions of Akhtar et al. (2012) that private school Head teachers attach a greater level of importance to the instructional supervision of newly recruited teachers.

This finding implies that, whenever school Heads attach a greater level of importance to the instructional supervision of beginning teachers, it will enable these teachers to develop themselves professionally since instructional supervision is a necessary ingredient for professional development. This will go a long way to improve or affect the academic performance of students.

Concerning the basic challenges school heads encounter in supervising Beginning SHS Economics teachers, it was evident that Head teachers face the basic challenges in instructional supervision. This finding validates the work of Odundo and Gunga (2013) that all supervisors will be faced with the basic challenges in instructional supervision as long as the supervisees are newly recruited. Again, the results of the study are in conjunction with that of Wang and Sullivan (2015) who contend that most of these newly appointed teachers disrespect and do not implement suggestions offered to them by their supervisors. Also, Scherman and Toit (2018) studies discovered that due to the workload of head teachers, it makes it difficult for them to take new teachers' through the proper steps in instructional supervision.

Supervisors across the length and breadth of the country are seen as incompetent by the various educational authorities. The underdevelopment of newly recruited teachers' professional development is always ascribed to their supervisors. However, this assertion may not be entirely true, because the study clearly shows that these basic challenges are the limiting factors that do not allow them to carry out their professional responsibilities smoothly.

With research hypothesis one, the findings revealed that there is no statistically significant difference between the level of importance male and female school heads attach to Beginning SHS Economics teacher's instructional supervision. It can, therefore, be concluded that both genders attach the same level of importance to instructional supervision.

Findings discovered disprove the findings of Kaenzig, Hyatt and Anderson (2007); Farrah (2011) and Reda (2015) who found out that there are significant differences between male and female supervisors on the level of importance attached to instructional supervision. Kaenzig, Hyatt and Anderson (2007) indicated that female supervisors attach a lesser level of importance towards the instructional supervision of teachers than male supervisors. Both of the genders see the relevance of teacher instructional supervision that is why they have attached a greater level of importance to it despite the challenges they face in the cause of instructional supervision. Even though Farrah discovered supervisors attach a greater level of importance to instructional supervision, finding significant differences between both genders is not supported by this study. Supervisors' attachment to a greater level of importance is not gender-sensitive as far as this study is concerned.

Therefore, Fultz and Herzog (1991) argument that female supervisors are conducting instructional supervision regularly for their supervisees as compared to their male counterparts. Again, 
even though Reda (2015) found out that supervisors attach a greater level of importance to instructional supervision which this study confirms, the findings that there were differences between the genders was inconsistent with the finding of this study. The environment supervisors seem to find themselves in could be the factor resulting in these differences as already indicated.

However, findings from this study validate that of Nausheen, Alvi, Munir and Awar (2013) and Amanfo and Asante (2014) who found out that there are no significant differences in the level of importance male and female supervisors attach to the instructional supervision of teachers. By this, it will be difficult to believe that instructional supervision is gender-sensitive. It is therefore very paramount for supervisors to conduct, as well as encourage both genders to regularly supervise to enhance the professional development of beginning teachers in their schools.

Concerning Research hypothesis two, the findings revealed that there is a statistically significant difference in the level of importance attach to Beginning SHS Economics teachers instructional supervision between private and public SHS Head teachers. This result suggests that Head teachers based on the school proprietorship attach a different level of importance to the instructional supervision of their Beginning SHS Economics teachers.

This finding provides support for the assertions of Oduro (2008) that there are differences in the level of importance Public and private School Heads attach to the instructional supervision of their newly recruited teachers. The finding further confirms the opinion of Augustyn (2011) who emphasized that the number of times instructional supervision is being conducted by school Heads is a function of their level of importance attached to instructional supervision. However, the finding is at variance with that of Okendu (2012) who found that both public and private schools Heads attach the same level of importance to the instructional supervision of their teachers.

The difference in the level of importance attached to instructional supervision between private and public Head teachers might be attributed to differences in their job security. Also, the difference can be linked to the fact that there is a vast difference in the professional qualification of private schools' heads and that of the public schools' heads. Also, the differences in the availability of resources can be another cause of this disparity.

\section{CONCLUSION}

Firstly, resources availability and substantial remuneration to supervisors was a necessary ingredient for school Heads to carry out their supervisory responsibilities effectively. Also, supervisors were still battling with the basic challenges of instructional supervision especially for beginning teachers that needs stakeholder's attention. Additionally, private Head teachers attach a greater level of importance to the instructional supervision of their supervisees which could be attributed to the fear of job insecurity.

\section{RECOMMENDATIONS}

Head teachers/supervisors should supervise their supervisees regularly and also organise in-service training for beginning teachers as a way of helping their supervisees improve their teaching. Also, head teachers/supervisors should have a more coherent job description. This implies a reduction in the role conflicts by de-linking control from advice functions and separating administrative from pedagogic tasks.

\section{REFERENCES}

[1] Abiola, H. (2011). Self-presentation bias in surveys of teachers' educational technology practices. Educational Technology Research and Development, 55(6), 627-646.

[2] Akhtar, I., Perveen, F., Kiran, G., Rashid, Y., \& Satti, W. (2012). The obstacles of instructional supervision in Riyadh schools. Unpublished master's thesis, King Saud University, Riyadh.

[3] Amanfo, P., \& Asante, A. (2014). The changing discourse of assessment policy: The case of English primary education. Social Practice and Social Product, 2(1), 11-26.

[4] Amoateng, K. (2015). Ensuring fair and reliable measures of effective teaching: culminating findings from the MET project's three-year study. Unpublished master thesis, King Saud University, Riyadh

[5] Ansong, M. G. (2013). Keeping score-using the right metrics to drive worldclass performance. New York: Quality Resources.

[6] Augustyn, G. J. (2011).Teacher supervisory preferences. Unpublished master's thesis, University of Saskatchewan, Saskachewan, Canada.

[7] Badu, K. G., \& Antwi, M. O. (2012). Implications of teachers' perception of instructional supervision in Basic Schools in Sekyere East District of Ghana. Ilorin Journal of Education, 27(4), 28-35

[8] Chen, Y. (2013). Enhancing professional practice: A framework for teaching. Alexandria, VA: Association for Instructional supervision and Curriculum Development

[9] Creswell, J. W. (2014). Research Design: Qualitative, Quantitative and Mixed Methods Approaches (4th ed.). Thousand Oaks, CA: Sage.

[10] Dale, D. L., \& Nasir, C., Sullivan, B., (2005). Subverting the academic absenteeism doctrine in teacher evaluation: How school reform legislation defeats itself. Brigham Young University Education and Law Journal, 1, 132140 .

[11] Dwamena, J. S. (2013). Researching Teacher Education: New Perspectives on Practice, Performance, and Policy, Multi-Site Teacher Education Research Project (MUSTER), Synthesis Report (No. 666-2016-45491).

[12] Ebmeier, R. W., \& Nicklaus, M. H. (2009). The employment interview handbook. Sage: Thousand Oaks.

[13] Farrah, M. H. (2011). Impacts of instructional supervision on teacher's professional development in Taiwan. Language, Culture and Curriculum, 28(2), 191-208.

[14] Fultz, M. S., \& Herzog, A. T. (1991). The narrowing of curriculum and pedagogy in the age of accountability. Urban Education, 42(6), 512-535.

[15] Gall, M. D., Gall, J. P., \& Borg, W. R. (2007). Educational research: An introduction (8th ed.). New York: Pearson Education.

[16] Ghana Education Service. (2019). The development of education national report of Ghana: The basic education division. Accra, Ghana: Government Publications.

[17] Glatthorn, A. A. (2010). Supervisory leadership: Introduction to instructiona supervision. Glenview, IC: Scott, Froes man, Brown Higher Education.

[18] Huling-Austin, R. S. (2000). Finding and framing a research question. In L. Patterson, C. M. Santa, K. G. Short, \& K. Smith (Eds.), Teachers are researchers: Reflection and action (pp. 19-25). Newark, DE: International Reading Association.

[19] Kaenzig, J., Hyatt, E. L., \& Anderson, E. (2007). The essence of research methodology: A consice guide for master and $\mathrm{PhD}$ students in management science. Springer: Heidelberg.

[20] Keeler, D., \& Steinhorst, K. (1995). An interview study of teachers' attitudes toward teacher evaluation practices. Journal of Research and Development in Education, 19(1), 32-37. 
[21] Kothari, C. R. (2004). Research methodology: Methods and techniques. New Age International.

[22] Nausheen, L. L., Alvi, J. W., Munir, H., \& Anwar, R., (2013). The headteacher's instructional role in academic achievement in secondary schools in Vihiga district, Kenya. Educational Research and Review, 3(10), 316-323.

[23] Odell, D. F., \& Ferraro, B. P. (2002). Essentials of nursing research: Methods, appraisal and utilization. (5th ed.). Philadelphia: Lippincott Williams \& Wilkins.

[24] Odundo, P. P., \& Gunga, H. J. (2013). Supervisory leadership: Introduction to instructional supervision. Glenview, IC: Scott, Froes man, Brown Higher Education.

[25] Oduro, G. (2008). Increased enrolment does not mean quality education [Electronic version]. Ghana News Agency. Retrieved on http:news. myjoyonline.com/education/

[26] Okendu, J. N. (2012). The influence of instructional process and instructional supervision on academic performance of secondary school students of Rivers State, Nigeria. Academic Research International, 3(1), 332-338.

[27] Omane, J. (2015). Effect of peer coaching on teachers' collaborative interactions and students' mathematics achievement. Journal of Educational Research, 102(3), 203-212.

[28] Onwuegbuzie, L. P., \& DaRose-Voseles, H. J. (2001). Supervisory leadership: Introduction to instructional supervision. Glenview, IC: Scott, Froes man, Brown Higher Education.

[29] Reda, R. P. (2005). Characteristics of an effective student testing system. Educational Horizons, 85(1), 19-29.

[30] Reiman, A. J., \& Thies-Sprinthall L. (1998). Mentoring and instructional supervision for teacher development. New York: Longman.

[31] Reiman, A. J., \& Thies-Sprinthall, L. (2008). Mentoring and instructional supervision for novice teacher development. New York: Longman.
[32] Robinson, T. (2008). Foundation of education. New York: Allyn and Bacon Co.

[33] Saahene, L. K. (2014). Instructional supervision: Teachers' and administrators' perceptions of instructional supervision in the Nkwanta District of Ghana. Unpublished masters' thesis, University of Cape Coast, Cape Coast.

[34] Scherman, S., Toit, T., (2018). Social research. (3rd ed.). London: Macmillan Press Ltd

[35] Sergiovanni, T. J., \& Starratt, R. J. (2008). Instructional supervision: A redefinition. (7th ed.). New York: McGraw-Hill.

[36] Wang, C., \& Sullivan, T. (2015). How tests change teaching: A model for reference. English Teaching: Practice and Critique, 8(2), 188-206.

\section{AUTHORS}

First Author - Dacoster Kwaku Boakye, Department of Business and Social Sciences Education, Faculty of Humanities and Social Sciences Education, University of Cape Coast, Cape Coast, Ghana, E-mail: boakyedacosta@gmail.com $+233248825481$

Second Author - Francis Arthur, Department of Business and Social Sciences Education, Faculty of Humanities and Social Sciences Education, University of Cape Coast, Cape Coast, Ghana, E-mail: a.francis1608@gmail.com +233246558939 https://orcid.org/0000-0001-7792-6563 